\title{
Amazing Sea Stories II
}

Since Roger Larson passed away earlier this year, I've repeatedly read his preface to ODP's Greatest Hits (July 1997), an abstract volume that collected the cutting-edge science that the Ocean Drilling Program (ODP) was doing nearly ten years ago (the booklet is available online at http://www. usssp-iodp.org/Publications/Greatest_Hits/brochure.html). At the time, Roger was a professor at the Graduate School of Oceanography, University of Rhode Island and chair of the Joint Oceanographic Institutions/U.S. Science Advisory Committee (JOI/USSAC), the group that advised the director of the JOI/U.S. Science Support Program (JOI/USSSP) on issues related to U.S. participation in ODP. (I was that director when the booklet was published and one of the booklet's editors.) It was only natural that Roger, as head of the U.S. drilling effort, write this preface.

A lover of science fiction, Roger titled his preface "Amazing Sea Stories" and wrote:

Before writing this preface I opened an old paperback book of early stories by Isaac Asimov, always one of my favorite science fiction writers. In his preface, Asimov described his experiences peddling 1930svintage stories to magazines named Astounding Science Fiction, Amazing Stories, and Thrilling Wonder Stories. While wallowing in this charming nostalgia I also marveled at the audacity of the magazine titles, designed to literally leap off the bookseller's shelf into the hands of an over-intelligent teenager like Asimov, or indeed like many of us. Titles help to sell the works within, and I like the title ODP's Greatest Hits for this abstract volume. However, I thought I'd go it one better and call this preface "Amazing Sea Stories," although this implies that at least some of them might not be true. Well, let's face it, maybe some of them aren't. With more time, more data, more models, and more thought, some of our current ideas will be discarded, although they were not originally conceived as science fiction.

ODP's Greatest Hits included abstracts about rapid climate change, evidence for microbes in oceanic basalts, sedimentary records of a large K/T boundary meteorite impact, vast stores of gas hydrates in the seafloor, subseafloor water circulation, and more. Several of those same topics are covered, now almost ten years later, in this volume of science articles. As Roger predicted, some ideas written about in the abstract volume have been discarded, while others have been refined as more scientists from more fields analyze more cores and run more downhole experiments with more sophisticated technology. As Roger put it:

... in the spring of 1967 when I was a graduate student and a year before Leg 1 of DSDP left the dock, one of our professors offered to bet anyone in the room \$20 that DSDP would recover a continuous Phanerozoic sediment section and bottom out in Precambrian basement beneath the deep seafloor. In doing this he echoed the views of the famous American geologist James D. Dana more than 100 years earlier who also believed in the fixity of continents and ocean basins. In addition to that he demonstrated it is hard to make major advances in scientific thinking without improved technology. As Bertolt Brecht put it, "Astronomy did not progress for 1,000 years because astronomers did not have a telescope." 


\section{Upcoming \\ Special-Issue Topics}

VOL. 20, NO. 1, MARCH 2007

InterRIDGE

Guest Editors: Colin Devey, IFM-GEOMAR;

Chuck Fisher, Penn State; and K. Okino,

University of Tokyo

VOL. 20, NO. 2, JUNE 2007

A SEA OF MICROBES

Guest Editors: Lita Proctor, The Gordon

and Betty Moore Foundation; and

David Karl, University of Hawaii

\section{VOL. 20, NO. 3, SEPTEMBER 2007} MARINE POPULATION CONNECTIVITY

Guest Editors: Robert Cowen, University of Miami; Simon Thorrold, Woods Hole Oceanographic Institution; Jesús Pineda, Woods Hole Oceanographic Institution; Glen Gawarkiewicz, Woods Hole Oceanographic Institution; and Cisco Werner, University of North Carolina, Chapel Hill

\section{VOL. 20, NO. 4, DECEMBER 2007}

OCEAN EXPLORER

Guest Editor: Stephen Hammond, National

Oceanic and Atmospheric Administration

VOL. 21, NO. 1, MARCH 2008

TBA

VOL. 21, NO. 2, JUNE 2008

CELEBRATING 50 YEARS OF INTERNATIONAL PARTNERSHIPS IN OCEAN RESEARCH

Guest Editor: Peter Ranelli, NATO Undersea Research Centre

The editorial staff also encourages unsolicited manuscripts on other oceanography themes for consideration and publication under the Regular Features banner.
As Roger recognized, every amazing sea story could only be written because someone behind the scenes, often unheralded, provided scientists with the tools needed to get the job done. Beyond the scientists who get the lion's share of kudos, it takes many others to run a successful program: the truly dedicated drilling crews on the ships; the travel specialists who arrange transportation to meetings and ports in sometimes remote places; the technicians who keep the shipboard and shorebased equipment working to permit acquisition of thousands of samples and analyses; and the engineers who help to design and build innovative equipment that allows us to obtain new and better data, drill deeper, and access more remote parts of the ocean. Credit should also go to the people who manage these programs and time and again ask us to describe in simpler terms our exciting science so that they can persuade agencies and legislators to continue funding our work. When reading this issue of Oceanography, let's take a moment to thank all the dedicated people who enable us to write these amazing sea stories and test whether our current theories will stand the test of time or be relegated to the annals of science fiction. There is still much work to be done. In closing his preface, Roger quoted Wilbur Wright: "We can see enough now to know that the next Century will be magnificent; only let us be the first to open the roads."

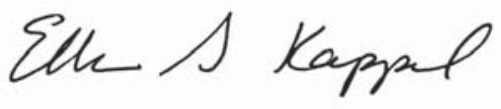

ELLEN S. KAPPEL, EDITOR

\section{THANK YOU...AND WELCOME}

After publication of this December issue, Nancy Caputo is stepping down as Assistant Editor. Nancy has done a tremendous job over the past three years. I will sorely miss her attention to detail and her outstanding knowledge of the editorial process. Nancy will be replaced by Vicky Cullen, who many of you know through her long publicationsrelated career at the Woods Hole Oceanographic Institution. Thank you, Nancy and welcome aboard, Vicky!

Ellen Kappel, Editor 